\title{
Biological proxies recorded in a Belukha ice core, Russian Altai
}

\author{
T. Papina ${ }^{1}$, T. Blyakharchuk ${ }^{2}$, A. Eichler ${ }^{3,4}$, N. Malygina ${ }^{1}$, E. Mitrofanova ${ }^{1}$, and M. Schwikowski ${ }^{3,4,5}$ \\ ${ }^{1}$ Institute for Water and Environmental Problems, SB RAS, Barnaul, Russia \\ ${ }^{2}$ Institute for Monitoring of Climatic \& Ecological Systems SB RAS, Tomsk, Russia \\ ${ }^{3}$ Paul Scherrer Institute, Villigen PSI, Switzerland \\ ${ }^{4}$ Oeschger Centre for Climate Change Research, University of Bern, Bern, Switzerland \\ ${ }^{5}$ Department of Chemistry und Biochemistry, University of Bern, Bern, Switzerland \\ Correspondence to: T. Papina (tanya.papina@ mail.ru)
}

Received: 30 April 2013 - Published in Clim. Past Discuss.: 21 May 2013

Revised: 9 September 2013 - Accepted: 24 September 2013 - Published: 30 October 2013

\begin{abstract}
Different biological proxies such as pollen, cysts, and diatoms were identified and quantified in the upper part of a Belukha ice core from the Russian Altai. The ice core from the Belukha glacier collected in 2001 (4062 m a.s.l., $49^{\circ} 48^{\prime} \mathrm{N}, 86^{\circ} 34^{\prime} \mathrm{E}$ ) was analyzed with annual resolution in the period 1964-2000. Daily data of the frequency of synoptic patterns observed in the Northern Hemisphere along with daily data of precipitation have been used to identify the predominant atmospheric circulations (elementary circulating mechanisms, or ECMs) generating the entry of biological proxies on the glacier surface. It was shown that the high-resolution records of diatoms, cysts, spores, and plant pollen in the Belukha ice core are the biological proxies for the changes in the structure of precipitation in the Altai region since these records can reflect changes in the contribution of different atmospheric circulation to annual or seasonal precipitation. The joint consideration of the transport ability of the biological species and the data of precipitation allowed us to determine the main modern sources of biological proxies deposited at the Belukha glacier. The main sources of diatoms in the Belukha ice core are water bodies of the Aral, Caspian, and northern Kazakhstan basins; coniferous tree pollen originated from the taiga forest of the boreal zone of western Siberia; pollen of deciduous trees and herbs from steppe and forest-steppe vegetation in the northern Altai and eastern Kazakhstan; and cysts and spores of plants were transported from local water bodies and forests. The identified source regions of the biological species are supported by back trajectory analyses and are in good agreement with emission source regions of the trace elements in the ice core.
\end{abstract}

\section{Introduction}

The biological species in an ice core of inland glaciers as the biological species in a sediment core of lakes are proxies for the paleoclimatic changes at the adjacent territories (Birks, 1981; Webb, 1985; Warner, 1988; Faegri and Iversen, 1989; Bennett et al., 1990; Holmes, 1992; Roberts, 1998; Eichler et al., 2011). The analysis of biological species in ice cores provides a valuable tool for the reconstruction of climate dynamics, regional vegetation, biological productivity, and forest fire history (Nakazawa and Fujita, 2006; Eichler et al., 2011; Mitrofanova et al., 2012). Plants and algae are characterized by specific seasonal growth and pollen production. Diatoms and chrysophycean algae are abundant in different water bodies during spring and autumn months, coniferous trees flower mainly in late spring to early summer, and deciduous trees and herbs at the end of spring and during all summer and early autumn. This seasonal occurrence of different species can be used as an additional and complementary tool to conventional methods for dating of an ice core (Nakazawa et al., 2004, 2005; Uetake et al., 2006; Santibañez et al., 2008).

The vast majority of aerosols (about $80 \%$ of the total quantity) fall out to the ground surface with precipitation, and only near $20 \%$ fall out through dry depositions (Croft et al., 2010). This statement is confirmed by other investigations and measurements (Fujita et al., 2000; Cong et al., 2010; Chou et al., 2011; Croft et al., 2012). The biological objects transported for a long distance, with other aerosols serving as the nucleus of atmospheric moisture condensation, can easily be involved in precipitation. Therefore we can 
assume that the biological objects as a component of aerosols mainly enter to the glacier surface with precipitation and not through dry depositions. Dry condition (the occurrence of updrafts and strong wind) promotes the admission of the biological species in the atmosphere, but after transporting for a long distance precipitation (not dry depositions) determines their falling on the ground surface. Therefore, atmospheric circulation patterns together with data on precipitation can give information about sources of biological objects in the ice layers. The high resolution of the ice core layers (up to one year) can provide the additional possibility of using the biological species as proxies for estimation of different atmospheric characteristics. Glaciers located on the boundary between contrasting climatic and vegetation zones are of most interest in this context.

The glaciers of the Altai Mountains located on the boundary between contrasting climatic and vegetation zones - i.e., the boreal forest zone in the north and the vast steppe belt of Kazakhstan to the west and southwest, and Mongolia to the south and southeast (Fig. 1) - are a good tool for the analysis of the regional climatic and environmental records. This region is equidistant from all the oceans and is affected by the major northern Eurasian circulation systems, i.e., the westerly jet stream and the Siberian High. The Atlantic, Arctic and Pacific oceans are considered to be the external moisture sources for this territory. Internal moisture sources refer to evaporation from continental sources, such as the closed Aral and Caspian basins, or convection from local basins, subjected to increased continental recycling (Aizen et al., 2005, 2006). Moisture transferred from the Mediterranean and the Black seas to the Altai Mountains is also considered to be evaporated from the internal moisture source. Thus, the Altai glaciers, in addition to climatic and environmental records, store information on internal and external hydrological cycles.

Ice cores from glaciers in the Altai Mountains have been proven to be invaluable archives of past eastern European air pollution (Olivier et al., 2006; Eichler et al., 2012), temperature changes in Siberia (Henderson et al., 2006; Eichler et al., 2009a; Okamoto, 2011) and variations in forest-fire activity and biogenic emissions from Siberian boreal forests (Eichler et al., 2009b, 2011). In the Altai region, glaciers are located above the tree line and the zone of alpine vegetation in the nival-glacial belt (Galakhov and Mukhametov, 1999); therefore all biological species found in glacial ice originated in other areas. Thus, biological species in the Altai glaciers can be a proxy record for changes of atmospheric conditions and atmospheric circulation pattern over the Altai and adjacent areas.

In this work, we investigate the relationship between concentrations of different biological objects (pollen, spores, cysts, and diatoms) discovered in the ice core from the Belukha glacier, Russian Altai (4062 ma.s.l., $49^{\circ} 48^{\prime} \mathrm{N}$, $86^{\circ} 34^{\prime} \mathrm{E}$ ), and contributions of different types of dominant atmospheric circulation to annual precipitation in the Altai
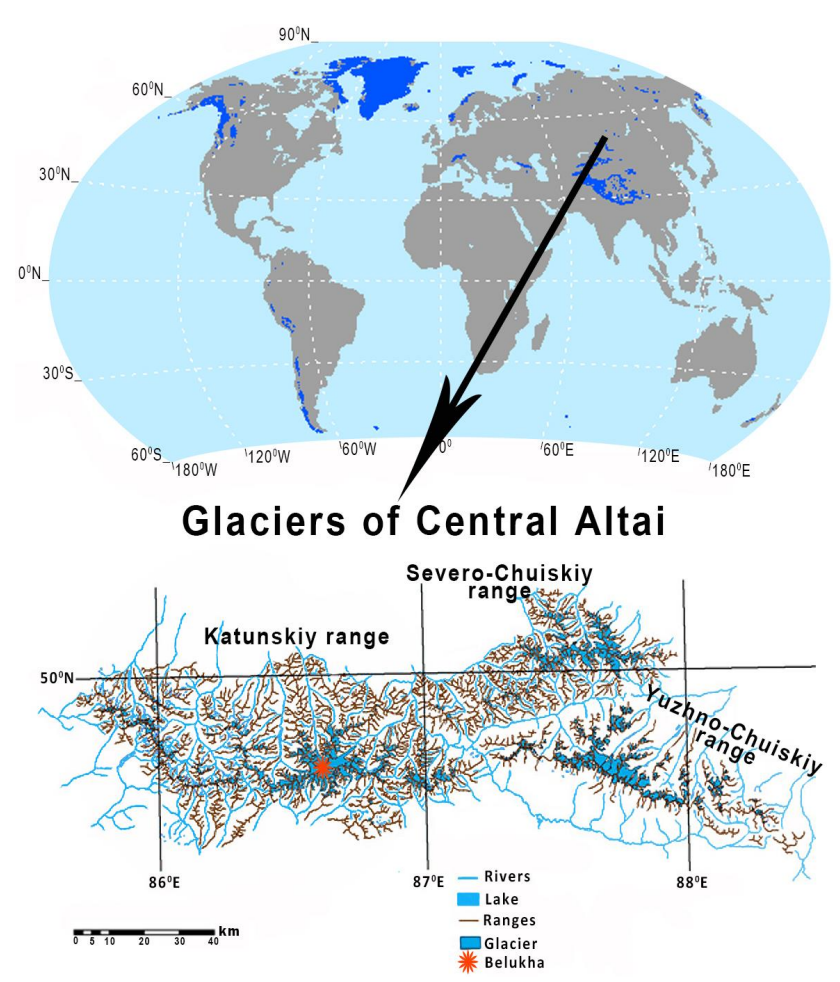

Fig. 1. Distribution of glaciers and ice around the world (except Antarctica) (GLIMS Glacier Database, 2012) and glaciers of central Altai (Kobyalko and Ostanin, 2012).

region. The main goal of our work was to show that changes of concentrations of the biological objects in the layers of the Belukha ice core can reflect the changes in the structure of precipitation in the Altai region (i.e., can reflect changes in the contribution of different atmospheric circulation to annual or seasonal precipitation). In this case the biological objects in the Belukha ice core can be the proxies for the changes in the structure of precipitation in the Altai region. The second goal of our work was to identify the sources of biological objects discovered in the Belukha ice core. In a previous study pollen was already investigated in this ice core covering the time period 1250-2001 (Eichler et al., 2011). The analysis revealed that the most remarkable vegetational shift during the investigated $750 \mathrm{yr}$ in the Altai region was a distinct decline of Pinus sibirica forests and a strong expansion of the Artemisia steppes around 1540-1680 AD, following very dry conditions and a period of exceptionally high forest-fire activity. However, this previous study was based on low-resolution and discontinuous pollen data only, with one sample covering about $30 \mathrm{yr}$.

Here we provide a high-resolution analysis of biological species in the Belukha ice core with annual resolution and get the records of the biological object concentration changes in the Belukha ice core for the period 1964-2000. Then using the daily data on the frequency of synoptic patterns (daily calendar of successive change of ECMs - elementary 
circulating mechanisms) observed in the Northern Hemisphere (Dzerdzeevskii, 1968, 1969; Kononova, 2009) and instrumental data of daily precipitation from the Kara-Tyurek weather station (located close to the Belukha glacier), we calculated the contribution (in \%) of each from 41 EMCs to annual (or seasonal) precipitation in the study area for the period 1964-2000 (for each year and for period in whole). In other words, we calculated how much precipitation fell down in the Altai region at different types of ECMs during a year (or a season of flowering and sporulation), and then calculated the percentages relatively the total annual (or seasonal) precipitation.

To determine the atmospheric processes that contribute to the deposition of biological objects at the Belukha glacier, we compared the changes in the amount of precipitation in the Altai region at different types of ECMs for years with maximum and minimum concentrations of biological proxies in the ice core. For this purpose for years with highest concentration of biological proxies, we identified the types of atmospheric circulation pattern providing, in the period of flowering and sporulation, the higher amount of precipitation relative to the average of these types for the corresponding circulation period. For years with the minimum concentration of biological proxies, we identified the types of atmospheric circulation pattern providing the lower amount of precipitation relative to the average of these types. If for years with the highest and the minimal concentrations of biological proxies we determined the same types of ECMs, it meant that these ECMs can define the deposition of biological objects onto the Belukha glacier. For these ECMs we calculated Pearson's correlation coefficient between concentrations of biological objects in the layers of the Belukha ice core and contribution (in \%) of EMC in annual precipitation. The analysis of the obtained results allowed us to identify the main sources of biological proxies deposited onto the glacier and showed that biological object discovered in the Belukha ice core can reflect changes of the contribution of different atmospheric circulation to annual (or seasonal) precipitation.

\section{Environmental setting and data sources}

\subsection{Regional settings}

The Altai mountain range has a northwest to southeast extension of $\sim 2100 \mathrm{~km}$ and is located on the boundary between Russia, Kazakhstan, China, and Mongolia. This region exhibits the highest degree of continentality in the world. The high-mountain part of the Altai (Belukha glacier, Katunsky ridge, Fig. 1) investigated in this study is characterized by a decrease of the mean annual precipitation near the snowline along the west-east axis from $2000 \mathrm{~mm}$ to less than $500 \mathrm{~mm}$ (Naroznyi and Osipov, 1999). As a result, the altitude of the snow line rises from $2400 \mathrm{~m}$ a.s.l. in the western part of Katunsky ridge to $3350 \mathrm{~m}$ a.s.l. at the Mongolian border. The main precipitation season in the Altai is in summer, whereas winter (December-February) accounts for less than $5 \%$ of the annual precipitation (Henderson et al., 2006). This is due to the prevailing stable Siberian High in winter and the predominance of cold and dry Arctic air masses. In summer humid air masses from the Atlantic Ocean and recycled moisture from central Asian sources are the main sources of precipitation (Aizen et al., 2005). In spite of the arid climate, the high altitudes of the ridges (up to $4506 \mathrm{~m}$ a.s.l., Belukha east summit) are favorable to glacier formation (Revyakin et al., 1979).

\subsection{Sources of the meteorological data}

For climatic analysis, we used $70 \mathrm{yr}$ long-term meteorological daily data on precipitation from the Kara-Tyurek $\left(49^{\circ} 57^{\prime} \mathrm{N}, 86^{\circ} 29^{\prime} \mathrm{E} ; 2600 \mathrm{~m}\right.$ a.s.l.) weather station located $15 \mathrm{~km}$ northwest of the Belukha glacier (RIHMI-WDC, 2012). Meteorological data from this station agree well with data of the Ak-kem weather station located $10 \mathrm{~km}$ north of the Belukha, but in contrast to the Ak-kem station the Kara-Tyurek instrumental data are continuous for the period 1940-2012.

Among all Altai weather stations, the data from these two stations have the highest correlation with air temperature and precipitation at Altai glaciers (Revyakin et al., 1979; Galakhov and Mukhametov, 1999).

\section{Methods}

\subsection{Sampling}

The drilling site is located on the Belukha glacier in the Russian Altai Mountains. In July 2001 a 139 m-long ice core was retrieved from the glacier saddle between the Belukha east and west summit ( $4062 \mathrm{~m}$ a.s. $1 ., 49^{\circ} 48^{\prime} 26^{\prime \prime} \mathrm{N}, 86^{\circ} 34^{\prime} 43^{\prime \prime} \mathrm{E}$ ) (Olivier et al., 2003). The ice core was transported frozen to the Paul Scherrer Institute (PSI), Switzerland, for sampling and glaciochemical, diatom, spore, and pollen analyses. Each ice core section with a length up to $70 \mathrm{~cm}$ (diameter $7.8 \mathrm{~cm}$ ) was processed in the cold room at $-20^{\circ} \mathrm{C}$. For cutting and decontamination a band saw with stainless-steel blades and Teflon-covered tabletops and saw guides were used. Outer core parts $(0.5-1 \mathrm{~cm})$ were used for $\delta^{18} \mathrm{O},{ }^{210} \mathrm{~Pb},{ }^{3} \mathrm{H}$, diatom, spore, and pollen analyses. Inner sections were taken for analysis of the major ions and trace elements.

\subsection{Dating}

Applying a combination of different dating methods the ice core was found to cover the period 1250-2001 AD (Eichler et al., 2009a). The time scale was derived using the ${ }^{210} \mathrm{~Pb}$ record, a three-parameter annual layer-counting methodology, and a nonlinear regression (Haefeli, 1961) through the reference horizons related to the maximum of nuclear 
weapons testing (1963 - ${ }^{3} \mathrm{H}$ maximum) and different volcanic eruptions (Henderson et al., 2006; Olivier et al., 2006; Eichler et al., 2009a). Volcanic horizons are marked by nondust $\mathrm{SO}_{4}{ }^{2-}\left(\mathrm{exSO}_{4}{ }^{2-}\right)$ concentration maxima and corresponding minima in the temperature record. The dating uncertainty is one year for the period 1964-2000 investigated in this study.

\subsection{Analyses of diatoms, spores, and pollen}

31 ice core samples were prepared for the analyses of diatoms, spores, and pollen. Sample processing was carried out using standard hydrobiological methods (Wetzel and Likens, 2000). About $0.3-0.5 \mathrm{~kg}$ ice was melted in a pre-cleaned glass container and subsequently the melt water was filtered (membrane filter, pore size $1 \mu \mathrm{m}$ ). The filter was rinsed with approximately $5 \mathrm{~mL}$ ultrapure water (Milli Q, $18 \mathrm{M} \Omega \mathrm{cm}$ quality). The biological objects in the suspended sample were counted using the counting chamber "Nazhotta" with a volume of $0.085 \mathrm{~mL}$ and a light microscope (Laboval 4) at $600 \times$ magnification. The results were expressed as unit or cell abundance using the formula

$N=n \times V_{1} \times\left(V_{2} \times V_{3}\right)^{-1} \times 1000^{-1}$,

where $N$ is number of biological objects, units $\mathrm{L}^{-1} ; n$ is number of biological objects in the counting chamber; $V_{1}$ is volume of the concentrated sample, $\mathrm{mL} ; V_{2}$ is volume of the sample, $\mathrm{mL}$; and $V_{3}$ is volume of the counting chamber, $\mathrm{mL}$.

Subsamples of biological material were dried on coverslips, coated with $\mathrm{Au}-\mathrm{Pd}$, and observed in a HITACHI S-3400 N scanning electron microscope for species identification.

Microscopic biological objects, their qualitative (taxonomic composition) and quantitative (relative participation of each taxonomical group in each ice sample) properties are used in this article for determining from what type of landscape they can originate. We based on the fact that each type of landscape produces specific type of pollen specters and other specific biological taxa such as diatoms, cysts of chrysophycean algae, etc. Here it should be noted that we put chrysophycean cysts, algae, Bryophyta and fungal spores in one group, because of their morphological similarity.

Geographic analyses revealed where major areas of such types of landscape are located. The Belukha Mts. geographically on a high scale are located on the boundary of different types of landscapes with different types of climate: boreal forest zone with wide deciduous (Betula pendula) and coniferous (Pinus sylvestris, Pinus sibirica, Abies sibirica, Picea obovata) forests in the north; desert, steppe and forest steppe (with Pinus sylvestris and Betula sp.) in the west; steppe and deserts in the south (in Mongolia) and mountain larch forests (Larix sibirica) and alpine and tundra-steppe vegetation in the east. Taking into account this background information the proper ECMs have been chosen which can most clearly

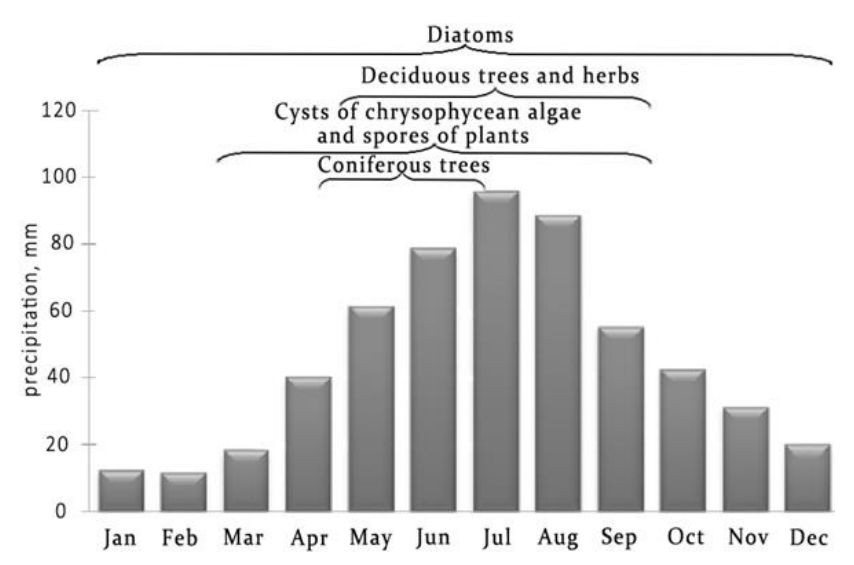

Fig. 2. Monthly precipitation in the Altai region (data of KaraTyurek meteorological station for period 1940-2000) and the time of flowering, sporulation, and cyst formation of biological objects discovered in the Belukha ice core.

explain how dominant airflow brings this or that particular type of biological proxies to the Belukha glacier.

\subsection{Classification of circulation mechanisms in the Northern Hemisphere (outside of tropics)}

To describe the atmospheric circulation patterns over the Altai region we used daily data on the frequency of synoptic patterns observed in the Northern Hemisphere (Dzerdzeevskii, 1975) for 6 sectors including the Siberian region. This classification was adopted by the World Meteorological Organization and described by Barry and Perry (1973). In the framework of this classification, it is assumed that fluctuations in atmospheric circulation are considered as the main component of climate variability and typical location and movement of cyclones and anticyclones occur regularly. Based on the analysis of synoptic (baric topography at $500 \mathrm{hPa}$ ) daily maps, 41 ECMs were identified. The important feature of the ECMs is that they are seasonal in nature; therefore ECMs are subdivided into summer $(\mathrm{s})$ and winter (w) subtypes. Characteristic indicators of the ECM identification were the presence or absence of blocking processes in the hemisphere, their quantity and direction as well as the amount and direction of cyclones coming from south (from the Mediterranean, Black and Aral seas). The border between the regions of high and low pressure passes along the isoline $1015 \mathrm{hPa}$. Each ECM has a unique cyclone and anticyclone trajectory scheme and description of fluctuation for the period 1899-2008 (Dzerdzeevskii, 1968; Kononova, 2009).

This used classification of atmospheric circulation patterns is the longest one. It takes into account the diversity of the circulation processes during all seasons for the study area, including rare ones coming from the east. Therefore, the use of this classification for the Altai region is preferable relative to other regional classifications of macrocirculation processes 
Table 1. Biological proxies discovered in the Belukha ice core.

\begin{tabular}{|c|c|c|c|c|}
\hline Objects & Species & $\begin{array}{l}\text { Concentration in the } \\
\text { ice core, units } \mathrm{L}^{-1}\end{array}$ & Distance of transport & Geographic referencing \\
\hline \multirow[t]{3}{*}{ Diatoms } & Hantzschia amphioxys & $0-11.1$ & \multirow[t]{3}{*}{$\begin{array}{l}\text { From few to thousands } \\
\text { of kilometers }\end{array}$} & $\begin{array}{l}\text { Cosmopolitan, in } \\
\text { reservoirs and mosses on } \\
\text { the rocks }\end{array}$ \\
\hline & Pinnularia borealis & $0-108.0$ & & North-alpine, littoral \\
\hline & Encyonema minutum & $0-1.9$ & & Cosmopolite, littoral \\
\hline $\begin{array}{l}\text { Cysts of chrysophycean } \\
\text { algae and spores of } \\
\text { plants (ferns and } \\
\text { Bryophyta) }\end{array}$ & $\begin{array}{l}\text { Spherical smooth forms } \\
\text { (not identified) }\end{array}$ & $6.0-61.9$ & $\begin{array}{l}\text { From few to thousands } \\
\text { of kilometers }\end{array}$ & $\begin{array}{l}\text { Mostly in cool-water } \\
\text { reservoirs } \\
\text { Boreal zone and forest } \\
\text { belt }\end{array}$ \\
\hline \multirow[t]{4}{*}{$\begin{array}{l}\text { Pollen of coniferous } \\
\text { trees }\end{array}$} & $\begin{array}{l}\text { Pinus sylvestris } \\
\text { (dominant) }\end{array}$ & \multirow[t]{4}{*}{$22.2-158.5$} & $500-1700 \mathrm{~km}$ & $\begin{array}{l}\text { Boreal forest zone and } \\
\text { forest altitude belt }\end{array}$ \\
\hline & Pinus sibirica & & $500-1700 \mathrm{~km}$ & $\begin{array}{l}\text { Boreal forest zone and } \\
\text { forest altitude belt }\end{array}$ \\
\hline & Picea obovata & & few $\mathrm{km}$ & Forest belt \\
\hline & Larix & & local & Forest belt \\
\hline \multirow[t]{4}{*}{$\begin{array}{l}\text { Pollen of deciduous trees } \\
\text { and herbs }\end{array}$} & $\begin{array}{l}\text { Betula sp. } \\
\text { (dominant) }\end{array}$ & \multirow[t]{4}{*}{$0-33.3$} & $250-400 \mathrm{~km}$ & Forest-steppe zone \\
\hline & Artemisia & & $300-500 \mathrm{~km}$ & Steppe \\
\hline & Chenopodiaceae & & $300-500 \mathrm{~km}$ & Desert \\
\hline & Poaceae & & few $\mathrm{km}$ & Steppe \\
\hline
\end{tabular}

developed for central Asia or for the winter period of Altai (Popova, 1972; Narozhnyi et al., 1993; Subbotina, 1995; Aizen et al., 2004, 2005, 2006).

In our work we used a daily calendar of successive change of ECMs (Kononova, 2009) and daily data on precipitation from the Kara-Tyurek weather station for calculating the contribution of each from 41 EMCs to annual (or seasonal) precipitation for the period 1964-2000. For this, we compared the daily calendar of successive change of ECMs with daily precipitation, determined ECMs under which precipitation fell down, and calculated the contribution (in \%) of each identified ECM to annual (or seasonal) precipitation.

\section{Results}

The different biological species identified in the Belukha ice core, including diatoms, pollen, cysts of chrysophycean algae, and spores of plants, are summarized in Table 1 . The flowering and sporulation periods of the identified species between March and November (Fig. 2) correspond with the main precipitation season in the Altai.

To determine the atmospheric processes that contributed to the deposition of biological objects at the Belukha glacier in the period 1964-2000, we compared the changes in the amount of precipitation in the Altai region at different types of ECM for years with maximum and minimum concentrations of biological proxies in the ice core. For this purpose for years with the highest concentration of biological proxies, we identified the types of atmospheric circulation pattern providing the higher amount of precipitation relatively to the average of these types for the corresponding circulation period. It appeared that there was no or significantly less precipitation under selected types of circulation than the average in years with a minimum concentration of biological proxies. The studied time period included two circulation periods for the Siberian region; the first lasted until 1980, and then it was replaced by the second one ("zonal circulation period") during 1981-2008 (Kononova, 2009). Since the maximum concentration of all identified biological objects in the ice core are within the period 1980-1990s, the calculation of average precipitation values for various types of ECM was performed for the period 1981-2000. A further justification for the use of this period only is that pollen productivity of individual plant species within the same plant communities can vary from year to year depending on the climatic conditions (Pardoe et al., 2010). However, pollen productivity for years within the dominant zonal circulation regime having similar 

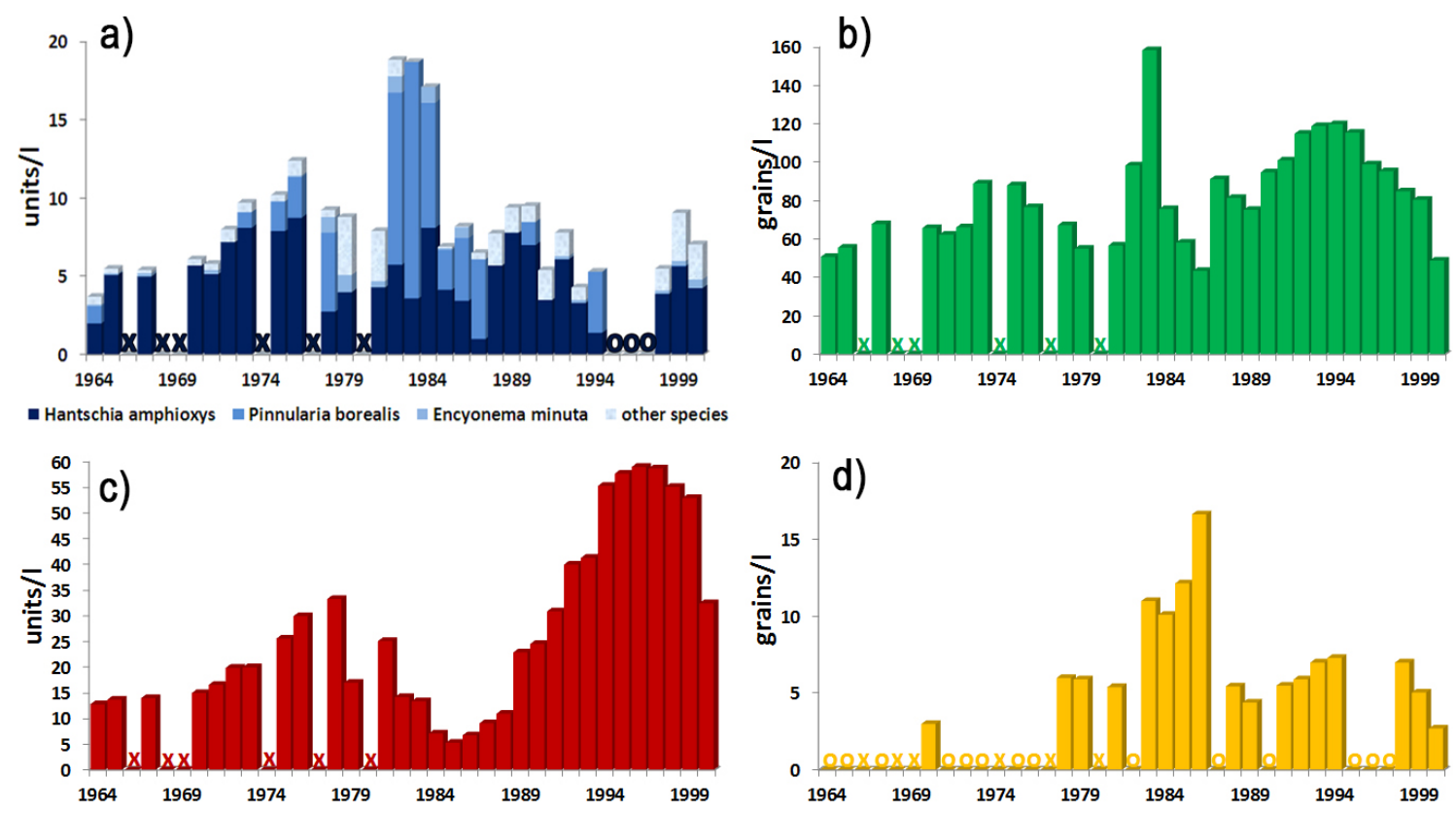

Fig. 3. Ice core records of diatoms (a); pollen of coniferous trees (b); cysts of chrysophycean algae and spores of plants (ferns and Bryophyta) (c); pollen of deciduous trees and herbs (d). ( $\mathrm{x}$ - sample is missing; 0 - biological objects are not discovered).

climatic conditions (Bezuglova et. al., 2012) is assumed to be not significantly different.

\subsection{Diatoms}

Diatom algae are not abundant in the Belukha ice core and have a low biodiversity. We identified the following species: Achnanthidium minutissimum (Kütz.) Czarnecki, Pinnularia borealis Ehr., Fragilaria ulna (Nitzsch) Lange-Bertalot var. ulna, Hantzschia amphioxys (Ehr.) Grun., Navicula cryptocephala Kütz., and Encyonema minutum (Hilse) Mann. Both $H$. amphioxys and $P$. borealis were most frequently observed among them. The largest numbers of $P$. borealis and $\mathrm{H}$. amphioxys were observed in the layer where diatoms in total had the maximum number (Table 2, Fig. 3a). It could be explained by the coming of more dry periods just after the humid ones, because these species are benthic and can be transported with an air mass from the bare littoral zone of different water bodies. In other layers mostly H. amphioxys was more abundant. We did not find specific (rare or endemic) diatom species. Most of the diatom species were pennate forms that live in bottom communities (phytoperiphyton or phytobenthos) of littoral zone in lakes and water streams. According to their geographical distribution they belong to the group of cosmopolitic forms. Valves of diatoms from the catchments can be transported by wind over thousands of kilometers. For example, frustules of fossil diatoms from Pleistocene sediments located in the south of Sahara were transported with air mass and fell down with the rains from time to time in London (Ross, 1988).
The ice core total and species-specific diatom records for the period 1964-2000 are shown in Fig. 3a. The most pronounced concentration maxima and minima occur during the periods 1982-1984 and 1995-1997, respectively. Types of ECMs leading to higher precipitation in 1982-1984 compared to the average of these types (period 1981-2000) are presented in Table 2. Characteristics and trajectories of these ECMs including the example of the dynamic scheme of type 10a are given in Table 2 and Fig. 4a. The analysis of these data shows that four ECMs (2b, 5a, 8b(s) and 10a) provide major precipitation relative to the mean average of these types in the years of maximal concentration of diatoms in the ice core. At the same time these types of circulation showed no or considerable less precipitation in years when diatoms were absent (1995-1997). During the diatom minimum year 1997, precipitation within type 10a was considerably higher than average. However, this precipitation occurred during the winter season, when the most water bodies (the main source of diatoms) were covered by ice. The correlation coefficients between number of diatom in the layers of the ice core and contribution of four predominant types of ECM to total amount of precipitation in the period 1980-2000 are quite high: $r^{2}=0.71$ for $2 \mathrm{~b}$ type of circulation; $r^{2}=0.69$ for $5 \mathrm{a}$; $r^{2}=0.57$ for $8 \mathrm{~b}(\mathrm{~s})$; and $r^{2}=0.56$ for $10 \mathrm{a}$. The correlation coefficient between number of diatom and total contribution of four predominant types of ECM $(2 b+5 a+8 b(s)+10 a)$ is $0.63(p<0.01)$.

Thus, for the period 1980-2000 most of the diatoms were transported to the Belukha glacier by cyclones that moved over the Black Sea, the Aral and Caspian basins as well as 
Table 2. Characteristics of atmospheric processes and a description of the trajectories of air masses over the Altai region and amount of precipitation (\% of the annual) at $2 \mathrm{~b}, 5 \mathrm{a}, 8 \mathrm{~b}(\mathrm{~s})$ and 10a ECM types in years of maximal (1982-1984) concentrations and absence (min) (1995-1997) of diatoms in the Belukha ice core (months of main precipitation are pointed in brackets).

\begin{tabular}{|c|c|c|c|c|c|c|c|c|c|}
\hline \multirow[t]{2}{*}{$\mathrm{ECM}$} & \multirow{2}{*}{$\begin{array}{l}\text { Meteorological } \\
\text { events over } \\
\text { Altai region }\end{array}$} & \multirow{2}{*}{$\begin{array}{l}\text { Trajectories of air } \\
\text { masses }\end{array}$} & \multicolumn{7}{|c|}{ Precipitation, $\%$} \\
\hline & & & $\begin{array}{l}\text { Average } \\
\text { for period } \\
1981- \\
2000\end{array}$ & $\begin{array}{l}1982 \\
(\max )\end{array}$ & $\begin{array}{l}1983 \\
(\max )\end{array}$ & $\begin{array}{l}1984 \\
(\max )\end{array}$ & $\begin{array}{l}1995 \\
(\min )\end{array}$ & $\begin{array}{l}1996 \\
(\min )\end{array}$ & $\begin{array}{l}1997 \\
(\min )\end{array}$ \\
\hline $2 b$ & $\begin{array}{l}\text { Mediterranean } \\
\text { cyclone }\end{array}$ & $\begin{array}{l}\text { Over the Black and } \\
\text { Caspian seas towards } \\
\text { the south of the Ural } \\
\text { and western Siberia, and } \\
\text { then to the northeast }\end{array}$ & 1.4 & $\begin{array}{l}10.1 \\
\text { (May, } \\
\text { Nov.) }\end{array}$ & $\begin{array}{l}3.9 \\
\text { (May) }\end{array}$ & $\begin{array}{l}2.8 \\
\text { (Jul.- } \\
\text { Aug.) }\end{array}$ & 0 & 0 & 0 \\
\hline $5 \mathrm{a}$ & $\begin{array}{l}\text { Mediterranean } \\
\text { cyclone }\end{array}$ & $\begin{array}{l}\text { Southern cyclones from } \\
\text { the eastern Mediter- } \\
\text { ranean Sea move through } \\
\text { the Aral-Caspian region } \\
\text { to basins of the Ob and } \\
\text { the Yenisei rivers }\end{array}$ & 0.8 & $\begin{array}{l}4.4 \\
\text { (Aug.) }\end{array}$ & $\begin{array}{l}5.9 \\
\text { (Aug.) }\end{array}$ & $\begin{array}{l}0.92 \\
\text { (Aug.) }\end{array}$ & 0 & 0 & $\begin{array}{l}0.5 \\
\text { (Nov.) }\end{array}$ \\
\hline $8 \mathrm{~b}(\mathrm{~s})$ & $\begin{array}{l}\text { Mediterranean } \\
\text { cyclone }\end{array}$ & $\begin{array}{l}\text { Through the south of the } \\
\text { Urals in the northeast di- } \\
\text { rection }\end{array}$ & 1.1 & $\begin{array}{l}3.7 \\
\text { (Jun.-- } \\
\text { Aug.) }\end{array}$ & $\begin{array}{l}4.8 \\
\text { (Aug.) }\end{array}$ & $\begin{array}{l}2.8 \\
\text { (Jun.-- } \\
\text { Jul.) }\end{array}$ & 0 & 0 & 0 \\
\hline $10 \mathrm{a}$ & $\begin{array}{l}\text { Cyclonic } \\
\text { breakthrough } \\
\text { from northern } \\
\text { Kazakhstan }\end{array}$ & $\begin{array}{l}\text { Ultrapolar invasions } \\
\text { through the Russian } \\
\text { Plain closed up with } \\
\text { local cyclonic from the } \\
\text { north of Kazakhstan and } \\
\text { further to the northeast }\end{array}$ & 3.2 & $\begin{array}{l}6.2 \\
\text { (May, } \\
\text { Oct.- } \\
\text { Dec.) }\end{array}$ & $\begin{array}{l}8.9 \\
\text { (Apr.- } \\
\text { May, } \\
\text { Jul., } \\
\text { Nov.) }\end{array}$ & $\begin{array}{l}3.9 \\
\text { (Apr., } \\
\text { Dec.) }\end{array}$ & $\begin{array}{l}1.5 \\
\text { (Jan.) }\end{array}$ & 0 & $\begin{array}{l}4.1 \\
\text { (Feb., } \\
\text { Nov.) }\end{array}$ \\
\hline
\end{tabular}

over the southern Ural and northern Kazakhstan. Water bodies of these regions are thus major sources of diatoms in the Belukha glacier.

\subsection{Pollen of coniferous trees}

Pollen of coniferous trees is the most abundant biological object in the Belukha ice core, i.e., Siberian pine (Pinus sibirica), Scot's pine (Pinus sylvestris), Spruce (Picea obovata) and more rarely Larix. Due to two special air sacs pollen grains of pine can be transported up to $1000 \mathrm{~km}$. At the territories adjacent to the Belukha glacier, pine pollen of $\mathrm{Pi}$ nus sylvestris and Pinus sibirica ripens during June - the first decade of July. Pollen of spruce (Picea obovata) is two times bigger and heavier than pollen of pines, its air sacs are smaller and it cannot move so far. Spruce pollen ripens in June. Larix pollen has no air sacs and does not fly far from native trees standing on mountain slopes. Its pollen ripens in April (the last decade) - May. We consider that pollen of spruce originates also from local spruce stands, growing in mixed forests in the valley of the Chuya River (Ogureeva, 1980). All pollen of Pinus sylvestris and part of pollen of Pinus sibirica (excluding pollen from mountain forests) have a long-distance origin from the boreal forest zone of western Siberia and the planes adjacent to the Altai Mts.

The concentration record of conifer tree pollen during the period 1964-2000 is presented in Fig. 3b. Maximum concentration falls on 1983, whereas a minimum was detected in 1986 and 2000. The analysis of ECMs demonstrated that the larger contribution to the annual precipitation in 1983 (compared to 1981-2000) was for three predominated types of circulation: $7 \mathrm{~b}(\mathrm{~s}), 8 \mathrm{~d}(\mathrm{~s}), 11 \mathrm{~d}$ (Table 3 ). Here, we need to point out that in 1983 more than two thirds of precipitation under types $8 \mathrm{~d}(\mathrm{~s})$ and $11 \mathrm{~d}$, and the whole precipitation under type $7 \mathrm{~b}(\mathrm{~s})$ was during the flowering season of pines, while in 1986 the major precipitation of $8 \mathrm{~d}(\mathrm{~s})$ occurred in the autumn and winter periods, when conifer pollen was not produced. The flowering season of pines has a very short period at the adjacent territories; therefore the concentration record of conifer tree pollen has to compare with changes of the dominant ECMs contribution relative to seasonal ("flowering") precipitation. The correlation coefficients between concentration of conifer tree pollen in the layers of the ice core and contribution of three predominant types of ECMs to total amount of seasonal (the last decade of April - the first decade of July) precipitation in the period 1980-2000 are sufficiently high: 

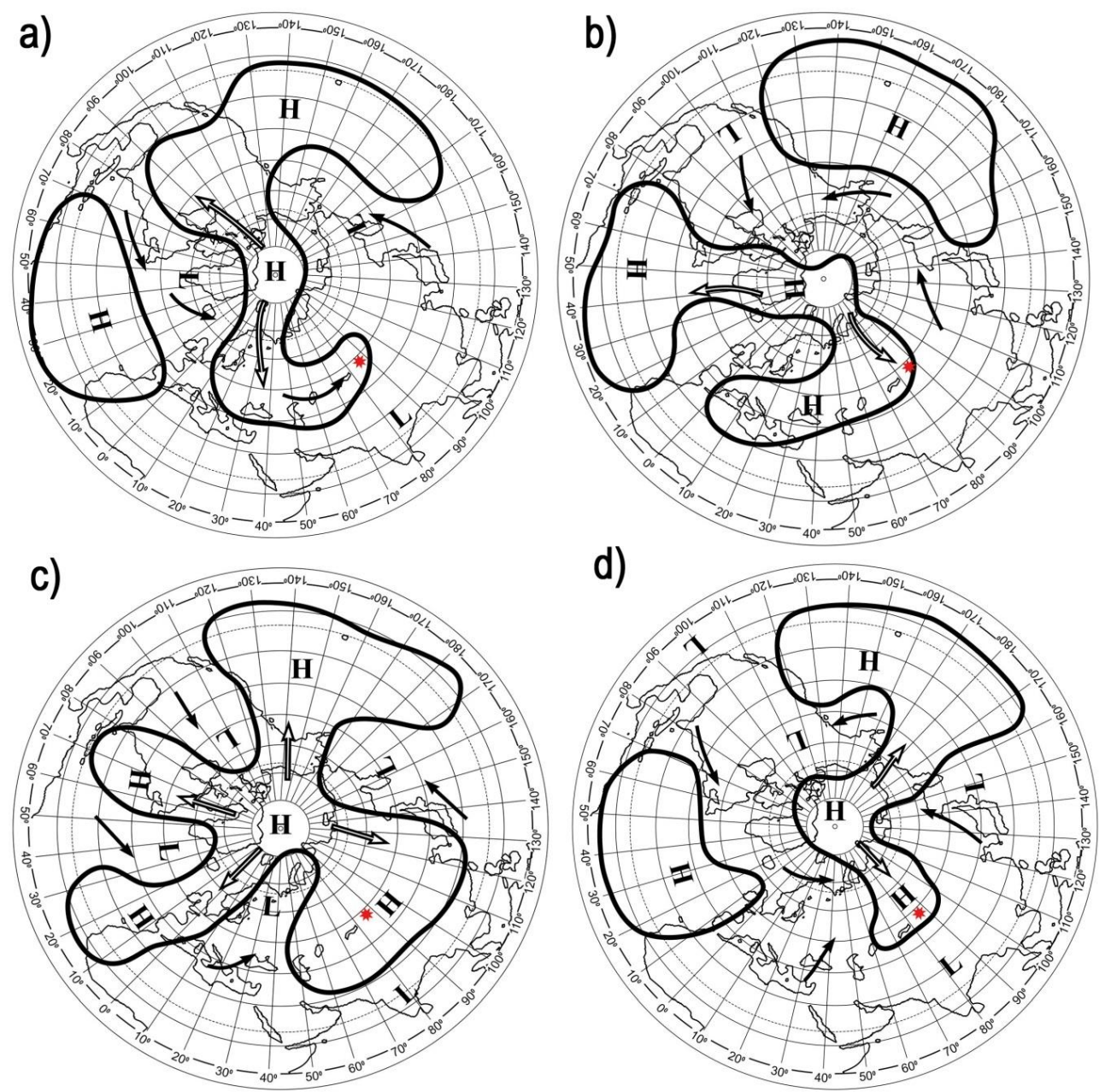

Fig. 4. Dynamic schemes of the ECMs: (a) 10a; (b) 8d(c); (c) 12a; (d) 8c(s). The border between the regions of high and low pressure passes along the isoline $1015 \mathrm{hPa}$ (bold curve). Arrows show the cyclonic (dark) and Arctic invasion (double light) tracks. Letters " $\mathrm{H}$ " and "L" denote high (anticyclone) and low atmosphere pressure (cyclone), respectively. Red asterisk $\left(^{*}\right)$ - Belukha glacier.

$r^{2}=0.44$ for $7 \mathrm{~b}(\mathrm{~s})$ type of circulation; $r^{2}=0.58$ for $8 \mathrm{~d}(\mathrm{~s})$; and $r^{2}=0.51$ for $11 \mathrm{~d}$. The correlation coefficient between number of conifer tree pollen and total contribution of predominant types of ECMs $(7 \mathrm{~b}(\mathrm{~s})+8 \mathrm{~d}(\mathrm{~s})+11 \mathrm{~d})$ to seasonal amount of precipitation is $0.61(p<0.01)$.

The origin and trajectories of the major circulation processes transporting pollen of conifer trees to the glacier are presented in Table 3. Figure $4 \mathrm{~b}$ demonstrates the dynamic scheme of the $8 \mathrm{~d}(\mathrm{~s})$ type of atmosphere circulation. The data from Table 3 and Fig. $4 \mathrm{~b}$ show that the major amount of precipitation in spring-summer of 1983 occurred at the Belukha glacier during ultrapolar invasions, when air masses arrived in the Altai region after passing above the large taiga zone of western Siberia. During this year considerable amount of precipitation fell on the Belukha glacier also due to formation of local cyclones on the periphery of the powerful Siberian High. Thus, we can conclude that the main sources of conifer pollen in layers of the Belukha glacier were taiga forests of northwestern Siberia and local mountain forests. Since spruce pollen (Picea obovata) is too heavy and cannot be transported over longer distances, it originates most likely from local spruce forests growing in the valley of the Chuya River.

\subsection{Cysts of chrysophycean algae and spores of plants (ferns and Bryophyte)}

Cysts of chrysophycean algae and spores of ferns and Bryophyta were found to be present in the ice core mainly by forms with a smooth surface. It is known that in eutrophic water bodies as well as in shallow pools the smooth forms of chrysophycean cysts mostly prevail. This is different in oligotrophic and deep pools, where forms with different elements on the surface dominate, which provides their floating in the water column (Bazhenova et al., 2012). Similar to diatoms, cysts of chrysophycean algae and spores of ferns and 
Table 3. Characteristics of atmospheric processes and a description of the trajectories of air masses over the Altai region and amount of precipitation (\% of the annual) $7 \mathrm{~b}(\mathrm{~s}), 8 \mathrm{~d}(\mathrm{~s})$ and $11 \mathrm{~d}$ ECM types in year of maximal (1983) and minimal (1986 and 2000$)$ concentrations of the pollen of coniferous trees in the Belukha ice core (months of main precipitation are pointed in brackets).

\begin{tabular}{|c|c|c|c|c|c|c|}
\hline \multirow[t]{2}{*}{ ECM } & \multirow{2}{*}{$\begin{array}{l}\text { Meteorological } \\
\text { events over } \\
\text { Altai region }\end{array}$} & \multirow{2}{*}{$\begin{array}{l}\text { Trajectories of air } \\
\text { masses }\end{array}$} & \multicolumn{4}{|c|}{ Precipitation, \% } \\
\hline & & & $\begin{array}{l}\text { Average } \\
\text { for period } \\
1981- \\
2000\end{array}$ & $\begin{array}{l}1983 \\
(\max )\end{array}$ & $\begin{array}{l}1986 \\
(\min )\end{array}$ & $\begin{array}{l}2000 \\
(\min )\end{array}$ \\
\hline $7 b(s)$ & $\begin{array}{l}\text { Cyclone- } \\
\text { anticyclone }\end{array}$ & $\begin{array}{l}\text { The formation of local } \\
\text { cyclone on the northern } \\
\text { periphery of the Asian } \\
\text { anticyclone }\end{array}$ & 0.9 & $\begin{array}{l}3.5 \\
\text { (May) }\end{array}$ & 0 & 0 \\
\hline $8 \mathrm{~d}(\mathrm{~s})$ & $\begin{array}{l}\text { Ultrapolar } \\
\text { invasions }\end{array}$ & $\begin{array}{l}\text { From north to south } \\
\text { through the whole } \\
\text { territory of the } \mathrm{Ob}^{\text {' basin }}\end{array}$ & 1.8 & $\begin{array}{l}13.1 \\
\text { (May- } \\
\text { Jul.) }\end{array}$ & $\begin{array}{l}4.5 \\
\text { (Jul.- } \\
\text { Sep.) }\end{array}$ & 0 \\
\hline $11 d$ & $\begin{array}{l}\text { Ultrapolar } \\
\text { invasions }\end{array}$ & $\begin{array}{l}\text { From northeast to south- } \\
\text { west through the whole } \\
\text { territory of eastern } \\
\text { Siberia }\end{array}$ & 2.0 & $\begin{array}{l}12.3 \\
\text { (Jun.- } \\
\text { Jul., } \\
\text { Sep.) }\end{array}$ & $\begin{array}{l}1.4 \\
\text { (Dec.) }\end{array}$ & $\begin{array}{l}1.7 \\
\text { (Nov.) }\end{array}$ \\
\hline
\end{tabular}

Bryophyta can be transported over hundreds to thousands of kilometers

The concentration record of chrysophycean algae cysts and spores of plants in the Belukha ice core is presented in Fig. 3c. Maximum and minimum concentrations were found during 1995-1997 and 1984-1986, respectively. During the maximum years only three types of ECMs occurred $(3,6$ and 12a), revealing higher than average precipitation (compared to 1981-2000). However, during types 3 and 6 precipitation was also higher than average in the minimum years (1984$1986 \mathrm{yr}$ ). For this reason, these types of ECMs were excluded from the analyses. Thus, type 12a is most probably the main type of ECM controlling the transport of cysts to the Belukha glacier (Table 4); the correlation coefficient between concentrations of chrysophycean algae cysts and spores of plants in the ice core and amount of precipitation at 12a type circulation is $0.55(p<0.01)$ for the period $1980-2000$. Under this type of circulation, a powerful anticyclone formed above the Asiatic part of Eurasia blocks the movement of western air masses (Fig. 4c). As a result, during such periods the main precipitation in the Altai originates from local cyclones (Table 4). The ECMs of this type most often are formed during the transition from the cold to the warm season, when the Arctic cyclone reaches its maximal power, and in southern areas the underlying ground surface is heated enough. Thus, the local water bodies and forests are probably the main sources of chrysophycean algae cysts and spores of plant.

\subsection{Pollen of deciduous trees and herbs}

Pollen of deciduous trees (Betula sp.) and herbs (including pollen of Artemisia, Cyperaceae, Asteraceae, and Poaceae families) is less abundant in the Belukha core. Pollen of birch (Betula) prevails among other species. The season of birch flowering is May. Its pollen can be transported up to $400 \mathrm{~km}$, and the closest birch forests are located $200-300 \mathrm{~km}$ to the west. The pollen maximum in the ice core was observed during 1983-1986, while a complete absence of pollen was observed in 1982, 1987, 1990, and 1995-1997 (Fig. 3d). Table 5 represents the ECMs, leading to higher than average precipitation in 1983-1986 and no precipitation in 1982, 1987, 1990, and 1995-1997. We excluded type 5b from the analysis, since in 1983-1986 the precipitation under this type of ECM occurred only in autumn, when plants did not bloom. Thus, only two summer types of ECMs $-8 \mathrm{c}(\mathrm{s})$ and $8 \mathrm{~d}(\mathrm{~s})$ - might control the transport of deciduous and herb pollen to the Belukha glacier (Table 5); for the period 1980-2000 the correlation coefficients between concentrations of pollen in the ice core and amount of precipitation at $8 \mathrm{c}(\mathrm{s})$ and $8 \mathrm{~d}(\mathrm{~s})$ types of circulation are 0.47 and 0.62 respectively. The correlation coefficient between pollen concentration and total amount of predominant types of ECMs $(8 \mathrm{c}(\mathrm{s})+8 \mathrm{~d}(\mathrm{~s}))$ is $0.68(p<0.01)$. Both types of circulation are characterized by powerful ultrapolar invasions from the northern areas of western Siberia to the south, where they hit warm continental air masses (Fig. 4d). This leads to the formation of an occluded front, when warm air masses uplift intensively (convective uplifting currents), involving aerosols from the underlying surface, including the plant pollen. The uplifting warm air masses replace cold air masses resulting in 
Table 4. Characteristics of atmospheric processes and a description of the trajectories of air masses over the Altai region and amount of precipitation (\% of the annual) 12a ECM types in years of maximal (1995-1997) and minimal (1984-1986) concentrations of cysts of chrysophycean algae and spores of plants in the Belukha ice core (months of main precipitation are pointed in brackets).

\begin{tabular}{|c|c|c|c|c|c|c|c|c|c|}
\hline \multirow[t]{2}{*}{ ECM } & \multirow{2}{*}{$\begin{array}{l}\text { Meteorological } \\
\text { events over } \\
\text { Altai region }\end{array}$} & \multirow{2}{*}{$\begin{array}{l}\text { Trajectories of } \\
\text { air masses }\end{array}$} & \multicolumn{7}{|c|}{ Precipitation, $\%$} \\
\hline & & & $\begin{array}{l}\text { Average for } \\
\text { period } \\
1981-2000\end{array}$ & $\begin{array}{l}1995 \\
(\max )\end{array}$ & $\begin{array}{l}1996 \\
(\max )\end{array}$ & $\begin{array}{l}1997 \\
(\max )\end{array}$ & $\begin{array}{l}1984 \\
(\min )\end{array}$ & $\begin{array}{l}1985 \\
(\min )\end{array}$ & $\begin{array}{l}1986 \\
(\min )\end{array}$ \\
\hline $12 \mathrm{a}$ & Anticyclone & $\begin{array}{l}\text { Anticyclone } \\
\left(30-0^{\circ} \mathrm{N},\right. \\
\left.45-140^{\circ} \mathrm{E}\right) \\
\text { blocks the } \\
\text { western air } \\
\text { mass transport }\end{array}$ & 5.6 & $\begin{array}{l}10.5 \\
\text { (Mar.- } \\
\text { Jul., } \\
\text { Nov.) }\end{array}$ & $\begin{array}{l}8.7 \\
\text { (Apr.- } \\
\text { May, } \\
\text { Sep.) }\end{array}$ & $\begin{array}{l}16.5 \\
\text { (May) }\end{array}$ & 0 & $\begin{array}{l}1.3 \\
\text { (Mar.- } \\
\text { Apr., } \\
\text { Sep.- } \\
\text { Oct.) }\end{array}$ & $\begin{array}{l}0.10 \\
\text { (Apr.- } \\
\text { May, } \\
\text { Sep.) }\end{array}$ \\
\hline
\end{tabular}

abundant precipitation and scavenging of bio-aerosols. Taking into account the fact that the distance of herb pollen transport does not exceed 250-400 km (Sladkov, 1967), the major sources of deciduous and herb pollen in the ice core are the steppe and forest-steppe areas of the northern Altai and eastern Kazakhstan.

\section{Discussion}

The period of instrumental observation of climatic parameters is short (at most $150 \mathrm{yr}$ ). In contrast, proxy data from natural archives such as glaciers, peat and lake deposits can cover periods of hundreds and thousands of years. The use of biological species as proxy data for continental ice cores holds much promise, since the continental glaciers, in contrast to the polar ones, are located in close proximity to the plant communities and have a high accumulation rate, which allows a high-resolution palynological analysis to be carried out (Mikhalenko, 2008). However, palynological studies of continental ice cores are not numerous (Liu et al., 1998, 2005; Nakazawa et al., 2004; Yang et al., 2010; Reese et al., 2013) although they have good applications.

It was shown that pollen in tropical ice cores can be used as an indicator of vegetation response to glacial-interglacial climate change sequences (Reese et al., 2013). The pollen record (as an independent biological proxy) from a Bolivian ice cap (Sajama) shows the same paleoclimatic trend as registered by the traditional chemical and physical parameters in two Peruvian ice cores hundreds of kilometers away and suggests that climatic changes associated with the LIA occurred synchronously across the central Andes (Liu et al., 2005). Studies of snow pits and an ice core in the Russian Altai demonstrated the potential for identifying and separating seasonal layers with high resolution by analyzing pollen taxa in samples as small as $10 \mathrm{~mL}$ (Nakazawa et al., 2004, $2005,2011,2012$ ). Ice core pollen data from the Belukha glacier suggest distinct forest diebacks and the expansion of steppe in response to dry climatic conditions (Eicher et al., 2011). The pollen record in the ice core from QinghaiTibetan Plateau (Shen et al., 2005) reveals a regional climate history similar to those from the neighboring sites, including the Arabian Sea and the Guliya ice core.

Our research shows that biological proxies can be interpreted not only in terms of accumulation, vegetation and landscape changes, but also in terms of predominant types of atmospheric circulations. The diatom, cyst, spore and plant pollen high-resolution records in the Belukha ice core can reflect changes in the contribution of different atmospheric circulation to annual (or seasonal) precipitation in the Altai region. It gives a new tool for investigation of atmospheric circulation in the pre-instrumental era in this region. Here, a special interest is the possibility to determine the seasonal changes in the structure of precipitation under the annual resolution of the ice core layers. The joint consideration of the transport ability of the biological object and the data on precipitation under predominant atmospheric ECMs allowed us to identify the origin of diatoms, cysts, spores and plant pollen discovered in the ice core. This result could be demanded and useful for the study of different aspects of the terrestrial transboundary atmospheric transport of substances.

\section{Conclusions}

The high-resolution records of diatom, cyst, spore, and plant pollen in the Belukha ice core are the biological proxies for the changes in the structure of precipitation in the Altai region because these records can reflect changes in the contribution of different atmospheric circulation to annual or seasonal precipitation. Since mostly precipitation (not dry depositions) determines the falling of aerosols (including bioaerosols) on the glacier surface and the extinction of plant species and deforestation of vast areas in Siberia were not observed for the last $40 \mathrm{yr}$ (the study time interval), the variation of pollen abundance in annual layers of the Belukha ice core together with other studied biological proxies (diatoms, 
Table 5. Characteristics of atmospheric processes and a description of the trajectories of air masses over the Altai region and amount of precipitation (\% of the annual) 8c(s) and 8d(s) ECM types in years of maximal (1983-1986) concentrations and absence (min) (1982, 1987, $1990,1995-1997)$ of pollen of deciduous trees and herbs in the Belukha ice core (months of main precipitation are pointed in brackets).

\begin{tabular}{|c|c|c|c|c|c|c|c|c|c|c|c|c|c|}
\hline \multirow[t]{2}{*}{ EÑM } & \multirow{2}{*}{$\begin{array}{l}\text { Meteorological } \\
\text { events over } \\
\text { Altai region }\end{array}$} & \multirow{2}{*}{$\begin{array}{l}\text { Trajectories of } \\
\text { air masses }\end{array}$} & \multicolumn{11}{|c|}{ Precipitation, $\%$} \\
\hline & & & $\begin{array}{l}\text { Average } \\
\text { for period } \\
1981- \\
2000\end{array}$ & $\begin{array}{l}1983 \\
(\max )\end{array}$ & $\begin{array}{l}1984 \\
(\max )\end{array}$ & $\begin{array}{l}1985 \\
(\max )\end{array}$ & $\begin{array}{l}1986 \\
(\max )\end{array}$ & $\begin{array}{l}1982 \\
(\min )\end{array}$ & $\begin{array}{l}1987 \\
(\mathrm{~min})\end{array}$ & $\begin{array}{l}1990 \\
(\min )\end{array}$ & $\begin{array}{l}1995 \\
(\min )\end{array}$ & $\begin{array}{l}1996 \\
(\min )\end{array}$ & $\begin{array}{l}1997 \\
(\min )\end{array}$ \\
\hline $8 c(s)$ & $\begin{array}{l}\text { Ultrapolar } \\
\text { invasions }\end{array}$ & $\begin{array}{l}\text { Ultrapolar invasions } \\
\text { through western } \\
\text { Siberia on the } \\
\text { background } \\
\text { of anticyclone }\end{array}$ & 1.1 & $\begin{array}{l}4.3 \\
\text { (May, } \\
\text { Aug.) }\end{array}$ & $\begin{array}{l}3.2 \\
\text { (Jun.- } \\
\text { Jul.) }\end{array}$ & $\begin{array}{l}1.8 \\
\text { (Apr.) }\end{array}$ & $\begin{array}{l}3.0 \\
\text { (Aug.) }\end{array}$ & 0 & 0 & 0 & $\begin{array}{l}0.7 \\
\text { (Apr.) }\end{array}$ & $\begin{array}{l}0.5 \\
\text { (Apr.) }\end{array}$ & 0 \\
\hline $8 \mathrm{~d}(\mathrm{~s})$ & $\begin{array}{l}\text { Ultrapolar } \\
\text { invasions }\end{array}$ & $\begin{array}{l}\text { Ultrapolar invasions } \\
\text { through western } \\
\text { Siberia on the } \\
\text { background } \\
\text { of anticyclone }\end{array}$ & 1.8 & $\begin{array}{l}12.9 \\
\text { (Apr.- } \\
\text { Jul., } \\
\text { Sep.) }\end{array}$ & $\begin{array}{l}4.0 \\
\text { (Mar., } \\
\text { Jul., } \\
\text { Sep.) }\end{array}$ & $\begin{array}{l}5.2 \\
\text { (Aug.) }\end{array}$ & $\begin{array}{l}4.05 \\
\text { (Jul.- } \\
\text { Aug.) }\end{array}$ & 0 & 0 & 0 & 0 & 0 & 0 \\
\hline
\end{tabular}

cysts, spores) can be used as a sensitive indicator of the atmospheric circulation dynamics in the Altai region. It was shown that different ECMs control the delivery of the identified biological aerosols on the glacier surface: $2 \mathrm{~b}, 5 \mathrm{a}, 8 \mathrm{~b}(\mathrm{~s})$ and 10a types of ECMs for diatoms; $7 \mathrm{~b}(\mathrm{~s}), 8 \mathrm{~d}(\mathrm{~s})$, and $11 \mathrm{~d}$ for pollen of conifer trees; $8 \mathrm{c}(\mathrm{s})$ and $8 \mathrm{~d}(\mathrm{~s})$ for pollen of deciduous trees and herbs; and 12a type for cysts of chrysophycean algae and spores of plants. Microscopic algae including frustules of diatoms and cysts of chrysophycean algae grow in water bodies all year round with their maximums in some seasons in contrast to the plant pollen produced in particular seasonal periods. Therefore their combination in the ice core makes it possible to determine the seasonal changes in the structure of precipitation under the annual resolution of the ice core layers, and thereby to get an outlook about past and future atmosphere circulation changes.

The joint consideration of the transport ability of the biological object and the data of precipitation under predominant atmospheric ECMs generating the entry of biological proxies on the glacier surface allowed us to determine the origin of diatoms, cysts, spores and plant pollen in the Belukha ice core. Frustules of diatoms could be brought mostly from the water bodies of the Aral, Caspian, and northern Kazakhstan basins, and the cysts of chrysophycean algae and spores of plants from local water bodies and forests surrounding the Belukha glacier. Pollen of coniferous trees prevailing in numbers in different layers of the ice core could be transported from the taiga forest of the boreal zone of western Siberia, and the pollen of deciduous trees and herbs from the steppe and forest-steppe vegetation of the northern Altai and eastern Kazakhstan.

The obtained source regions of the biological species are in good agreement with back trajectory analyses and emission source regions of the trace elements in the ice core (e.g., Eichler et al., 2009b, 2012).
Acknowledgements. We would like to thank Patrick Ginot and Beat Rufibach for drilling; and Martin Lüthi, Susanne Olivier, Henrik Rhyn, Dimitrii N. Kozlov, Sergej Derewstschikow, Vladimir Vashenzev, Andrej Jerjomin, Veronica Morozova, Alexander Chebotkin, and Igor Karakulko for their help during the expedition. We thank the Organizing Committee of IPICS OSC for the opportunity to represent our work and for financial support. This work was supported by Russian Academy of Sciences (Integration Project No 4.11), and by Russian Foundation for Basic Research (grants RFBR-13-04-00984).

Edited by: C. Barbante

\section{References}

Aizen, V. B., Aizen, E. M., Melack, J. M., Kreutz K. J., and Cecil, L. D.: Association between atmospheric circulation patterns and firn-ice core records from the Inilchek glacierized area, central Tien Shan, J. Geophys. Res., 109, D08304, doi:10.1029/2003JD003894, 2004.

Aizen, V. B., Aizen, E., Fujita, K., Nikitin, S. A., Kreutz, K. J., and Takeuchi, N.: Stable-isotope time series and precipitation origin from firn-core and snow samples, Altai glaciers, Siberia, J. Glaciol., 51, 637-654, 2005.

Aizen, V. B., Aizen, E. M., Joswiak, D. R., Fujita, K., Takeuchi, N., and Nikitin, S. A.: Climatic and atmospheric circulation pattern variability from ice-core isotope/geochemistry records (Altai, Tien Shan and Tibet), Ann. Glaciol., 43, 49-60, 2006.

Barry, R. and Perry, A.: Synoptic Climatology, Methods and Applications, Harper Collins, New York, 555, 1973.

Bazhenova, O. P., Mitrofanova, E. Y., and Shakhoval, V. E.: Stomatocysts of Chrysophyte Algae from Water Bodies of the Territory Near the Irtysh River in the Omsk Region and Lake Teletskoe (Mountainous Altay, Russia), Contemparary Problems of Ecology, 4, 571-578, 2012.

Bennett, K. D., Simonson, W. D., and Peglar, S. M.: Fire and man in post-glacial woodlands of eastern England, J. Archaeol. Sci., 17, 635-642, 1990. 
Bezuglova, N. N., Zinchenko, G. S., Malygina, N. S., Papina, T. S., and Barlyaeva, T. V.: Response of high-mountain Altai thermal regime to climate global warming of recent decades, Theor. Appl. Climatol., 110, 595-605, doi:10.1007/s00704-012-0710-2, 2012.

Birks, H. J. B.: The use of pollen analysis in the reconstruction of past climates: a review, in: Climate and history, edited by: Wigley, T. M. L., Ingram, M. J., and Farmer, G., Studies in past climates and their impact of man, Cambridge University Press, Cambridge, 111-138, 1981.

Chou, C., Stetzer, O., Weingartner, E., Jurányi, Z., Kanji, Z. A., and Lohmann, U.: Ice nuclei properties within a Saharan dust event at the Jungfraujoch in the Swiss Alps, Atmos. Chem. Phys., 11, 4725-4738, doi:10.5194/acp-11-4725-2011, 2011.

Cong, Z., Kang, S., Zhang, Y., and Li, X.: Atmospheric wet deposition of trace elements to central Tibetan Plateau, Appl. Geochem., 25, 1415-1421, 2010.

Croft, B., Lohmann, U., Martin, R. V., Stier, P., Wurzler, S., Feichter, J., Hoose, C., Heikkilä, U., van Donkelaar, A., and Ferrachat, S.: Influences of in-cloud aerosol scavenging parameterizations on aerosol concentrations and wet deposition in ECHAM5-HAM, Atmos. Chem. Phys., 10, 1511-1543, doi:10.5194/acp-10-1511-2010, 2010.

Croft, B., Pierce, J. R., Martin, R. V., Hoose, C., and Lohmann, U.: Uncertainty associated with convective wet removal of entrained aerosols in a global climate model, Atmos. Chem. Phys., 12, 10725-10748, doi:10.5194/acp-12-10725-2012, 2012.

Dzerdzeevskii, B. L.: Circulation mechanisms in the Northern Hemisphere atmosphere in 20-th century. Data of meteorological studies, Circulation of Atmosphere, International geophysical year, Institute of Geography of the USSR Academy of Sciences and Interagency Geophysical Committee of the Presidium of the USSR Academy of Sciences, 240 pp., 1968 (in Russian with English summary and contents).

Dzerdzeevskii, B.: Climatic epochs in the twentieth century and some comments on the analysis of past climates, in: Quaternary Geology and Climate: Proc. of the VII INQUA Congress, Nat. Acad. Sci., Washington, 49-60, 1969.

Dzerdzeevskii, B. L.: Selected works. General atmospheric circulation and climate, Nauka, Moscow, 288, 1975 (in Russian).

Eichler, A., Oliver, S., Henderson, K., Laube, A., Beer, J., Papina, T., Gäggeler, H. W., and Schwikowski, M.: Temperature response in the Altai region lags solar forcing, Geophys. Res. Lett., 36, L01808. doi:10.1029/2008GL035930, 2009a.

Eichler, A., Brutsch, S., Olivier, S., Papina, T., and Schwikowski, M: A 750 year ice core record of past biogenic emissions from Siberian boreal forests, Geophys. Res. Lett, 36, L18813, doi:10.1029/2009GL038807, 2009b.

Eichler, A., Tinner, W., Brutsch, S., Olivie, S., Papina, T., and Schwikowski, M.: An ice-core based history of Siberian forest fires since AD 1250, Quaternary Sci. Rev., 30, 1027-1034, doi:10.1016/j.quascirev.2011.02.007, 2011.

Eichler, A., Tobler, L., Eyrikh, S., Gramlich, G., Malygina, N., Papina, T., and Schwikowski, M.: Three Centuries of Eastern European and Altai Lead Emissions Recorded in a Belukha Ice Core, Environ. Sci. Technol., 46, 4323-4330, doi:10.1021/es2039954, 2012.
Faegri, K. and Iversen, J.: Textbook of pollen analysis, 4th Edn., edited by: Fægri, K., Kaland, P. E., and Krzywinski, K., John Wiley \& Sons, Chichester, 328, 1989.

Fujita, S., Takahashi, A., Weng, J.-H., Huang, L.-F., Kim, H.-K., Li, C.-K., Huang, F., and Jeng, F.-T.: Precipitation chemistry in East Asia, Atmos. Environ., 34, 525-537, 2000.

Galakhov, V. P. and Mukhametov, R. M.: Glaciers of the Altai, Nauka, Novosibirsk, 136, 1999 (in Russian).

GLIMS Glacier Database, available at: http://nsidc.org/glims/ (last access: 5 December 2012), 2012.

Haefeli, R.: Contribution to the movement and the form of ice sheets in the Arctic and Antarctic, J. Glaciology, 3, 1133-1151. 1961.

Henderson, K., Laube, A., Gäggeler, H. W., Olivier, S., Papina, T., and Schwikowski, M.: Temporal variations of accumulation and temperature during the past two centuries from Belukha ice core, Siberian Altai, J. Geophys. Res., 111, D03104, doi:10.1029/2005JD005819, 2006.

Holmes, J. K.: Nonmarine ostracods as Quaternary palaeoenviromental indicators, Prog. Phys. Geogr., 16, 405-431, 1992.

Kobyalko, R. A. and Ostanin, O. V.: Modern glaciation of the Central Altai, in: Geographical research of young scientists in Asia, Barnaul - Belokurikha, Russia, 20-24 November 2012, 117121, 2012 (in Russian).

Kononova, N. K.: Classification of Circulation Mechanisms of the Northern Hemisphere based on B. L. Dzerdzeevskii, Institute Geography Russian Academy of Sciences, Voentechinizdat, Moscow, 372, 2009 (in Russian with English title, summary foreword, introduction, conclusion and contents).

Liu, K. B., Yao, Z., and Thompson, L. G.: A pollen record of Holocene climatic changes from the Dunde ice cap, QinghaiTibetan Plateau, Geology, 26, 135-138, 1998.

Liu, K. B., Reese, C. A., and Thompson, L. G.: Ice-core pollen record of climatic changes in the central Andes during the last 400 yr, Quaternary Res., 64, 272-278, 2005.

Mikhalenko, V. N.: Inner structure of glaciers in non-polar regions, LKI Press, Moscow, 320, 2008 (in Russian).

Mitrofanova, E., Malygina, N., Papina, T., Eichler, A., Herren, P. A., and Schwikowski, M.: Biological species recorded in Belukha (Siberian Altai) and Tsambagarav (Mongolian Altai) ice core, Annual report, Paul Scherrer Institut, University of Bern, Switzeland, 98, 2012.

Nakazawa, F. and Fujita, K.: Use of ice cores from glaciers with melting for reconstructing mean summer temperature variations, Ann. Glaciol., 43, 167-171, doi:10.3189/172756406781812302, 2006.

Nakazawa, F., Fujita, K., Uetake, J., Kohno, M., Fujiki, T., Arkhipov, S. M., Kameda, T., Suzuki, K., and Fujii, Y.: Application of pollen analysis to dating of ice cores from lower-latitude glaciers, J. Geophys. Res. 109, F04001. doi:10.1029/2004JF000125, 2004.

Nakazawa, F., Fujita, K., Takeuchi, N., Fujiki, T., Uetake, J., Aizen, V., and Nakawo, M.: Dating of seasonal snow/firn accumulation layers using pollen analysis, J. Glaciology, 51, 483-490, doi:10.3189/172756505781829179, 2005.

Nakazawa, F., Miyake, T., Fujita, K., Takeuchi, N., Uetake, J., Fujiki, T., Aizen, V., ani Nakawo, M.: Establishing the Timing of Chemical Deposition Events on Belukha Glacier, Altai Mountains, Russia, Using Pollen Analysis, Arctic, Antarct. Alpine Res., 43, 66-72, 2011. 
Nakazawa, F., Konya, K., Kadota, T., and Ohata, T.: Reconstruction of the depositional environment upstream of Potanin Glacier, Mongolian Altai, from pollen analysis, Environ. Res. Lett., 7, 035402, doi:10.1088/1748-9326/7/3/035402, 2012.

Narozniy, Ju. K. and Osipov, A. V.: Oroclimatic conditions of the Central Altai glaciations, News Russian Geogr. Soc., 131, 4957, 1999 (in Russian).

Narozniy, Ju. K., Narojnaya, O. V., and Popova K. I.: Circulation regime and hydrothermal conditions winters, Altai, 4, 183-188, 1993 (in Russian).

Ogureeva, G. N.: Botanical geography Altai, Nauka, Moscow, 190, 1980 (in Russian).

Okamoto, S., Fujita, K., Narita, H., Uetake, J., Takeuchi, N., Miyake, T., Nakazawa, F., Aizen, V. B., Nikitin, S. A., and Nakawo, M.: Reevaluation of the reconstruction of summer temperatures from melt features in Belukha ice cores, Siberian Altai, J. Geophys. Res., 116, D02110, doi:10.1029/2010JD013977, 2011

Olivier, S., Schwikowski, M., Brütsch, S., Eyrikh, S., Gäggeler, H.W., Lüthi, M., Papina, T., Saurer, M., Schotterer, U., Tobler, L., and Vogel, E.: Glaciochemical investigation of an ice core from Belukha glacier, Siberian Altai, Geophys. Res. Lett., 30, 2019, doi:10.1029/2003GL018290, 2003.

Olivier, S., Blaser, C., Brütsch, S., Frolova, N., Gäggeler, H. W., Henderson, K. A., Palmer, A. S., Papina, T., and Schwikowski, M.: Temporal variations of mineral dust, biogenic tracers, and anthropogenic species during the past two centuries from Belukha ice core, Siberian Altai, J. Geophys. Res., 111, D05309, doi:10.1029/2005JD005830, 2006.

Pardoe, H. S., Giesecke, T., van der Knaap, W. O., SvitavskaSvobodova, H., Kvavadze, E. V., Panajiotidis, S., Gerasimidis, A, Pidek, I., Zimny, M., Swięta-Musznicka, J., Latałowa, M., Noryskiewicz, A. M., Bozilova, E., Tonkov, S., Filipova-Mrinova, M. V., Van Leeuwen, J., and Kalniòa, L.: Comparative pollen spectra from modified Tauber traps and moss samples: examples from a selection of woodlands across Europe, Veget. Hist. Archaeobot., 19, 271-283, 2010.

Popova, K. I.: About the type of annual precipitation distribution in Altai Mountains, Glaciologiya Altaya, 7, 169-174, 1972 (in Russian).

Reese, C. A., Liu, K. B., and Thompson, L. G.: An ice-core pollen record showing vegetation response to Late-glacial and Holocene climate changes at Nevado Sajama, Bolivia, Ann. Glaciol., 54, 183-190, 2013.
Revyakin, V. S., Galakhov, V. P., and Goleshchikhin, V. P.: Gornolednikovye basins Altai, Tomsk State University, Tomsk, 310, 1979 (in Russian).

RIHMI-WDC: available at: http://aisori.meteo.ru/ClimateR (last access: 20 April 2012), 2012.

Roberts, N.: The Holocene, An Environmental History, Blackwell Publishers, Oxford, 316, 1998.

Ross, R.: Endemism and cosmopolitism of diatom algae of Great African Lakes, Biosphere. Evolution, space and time, Progress, Moscow, 142-156, 1988.

Santibañez, P., Kohshima, S. Scheihing, R. Jaramillo, J., Shiraiwa, T., Matoba, S., Kanda, D., Labarca, P., and Casassa, G.: Glacier mass balance interpreted from biological analysis of firn cores in the Chilean lake district, J. Glaciol., 54, 452-462, 2008.

Shen, C., Tang, L., Wang, S., Li, C., and Liu, K.: Pollen records and time scale for the RM core of the Zoige Basin, northeastern Qinghai-Tibetan Plateau Chinese, Science Bulletin, 50, 553-562, 2005.

Sladkov, A. N.: Introduction in the spore-pollen analysis, Nauka, Moscow, 275, 1967.

Subbotina, O. I.: Atmospheric circulation, in: Change of climate in middle Asia, SARNIIGMI Publishing, Tashkent, 8-34, 1995 (in Russian).

Uetake, J., Kohshima, S., Nakazawa, F., Suzuki, K., Kohno, M., Kameda, T., Arkhipov, S., and Fujii, Y: Biological ice-core analysis of Sofiyskiy glacier in the Russian Altai, Ann. Glaciol., 43, 70-78, 2006

Warner, B. G.: Methods in Quaternary ecology 5, Testate amoebae (Protozoa), Geiscience Canada, 15, 251-260, 1988.

Webb, T.: Holocene palynology and climate, in: Paleoclimate analysis and modeling, edited by: Hecht, A. D., Chichester: J. Wiley \& Sons, 455, 1985.

Wetzel, R. G. and Likens, G. E.: Limnological Analyses, 3rd Edn., Springer-Verlag New York, Inc., 429, 2000.

Yang, B., Tang, L. Y., Li, C. H., Shao, Y., J., Tao, S. C., and Yang, L. Q.: An ice-core record of vegetation and climate changes in the central Tibetan Plateau during the last 550 years, Chinese Science Bulletin, 55, 1169-1177, 2010. 